\title{
The mediating role of self-care activities in the stress-burnout relationship
}

\begin{abstract}
BACKGROUND
Helping professionals suffer from a number of health and psychological difficulties resulting from their occupation. In the field of helping professions, the demand for understanding the predictors of burnout has been rapidly emerging. The aim of this study is to analyse and identify the possible mediators between stress and the three factors of burnout in a specific sample of helping professionals.
\end{abstract}

\section{PARTICIPANTS AND PROCEDURE}

Helpers $(N=698 ; 618$ women $)$ were randomly selected from institutions in 8 districts in Slovakia. The sample comprised social workers $(n=188)$; residential care providers $(n=191)$; ergotherapists $(n=97)$; providers of physical and psychological care (nurses, physiotherapists, psychologist and psychotherapists; $n=222$ ). They described their levels of perceived stress, risk of burnout (in three factors: emotional exhaustion, depersonalisation, and personal accomplishment) and performed self-care activities in selfreported questionnaires.
RESULTS

The relationship between stress and emotional exhaustion was mediated by health self-care. In comparison, the relationship between stress and depersonalisation was mediated by psychological self-care. The relationship between stress and personal accomplishment was mediated by both psychological and professional self-care.

\section{CONCLUSIONS}

When helping professionals have initial symptoms of burnout in the form of emotional exhaustion, concentrating on health self-care activities could be helpful. Performing health, psychological and professional self-care activities may prevent further development of burnout in times of high stress.

\section{KEY WORDS}

perceived stress; helping profession; social service; preventive factors 


\section{BACKGROUND}

Helping professionals working in the sphere of social and health services experience increasing psychosocial stress (Mahoney, 1997). Whitaker, Weismiller, Clark, and Wilson (2006) specified that the sources of stress include the amount of time spent with clients, lack of resources, low pay, being pressed for time, difficult caseload, decreased sense of security, and persistent problem situations. Mahoney (1997) found that helping professionals suffer from a number of health and psychological difficulties resulting from their occupation. The most important psychological difficulties were irritability, emotional exhaustion, lack of sleep, doubts about progress in therapeutic and occupational processes, concerns about the severity of cases, problems in intimate relationships, anxiety and depression (Barnett \& Cooper, 2009). Helping professionals work in demanding job conditions with a great deal of responsibility (Havrdová \& Šolcová, 2012) and emotional strains (Lloyd, King, $\&$ Chenoweth, 2002). Barnett and Cooper (2009) clarify that helping professionals provide assistance to others, although their own internal and external resources may be overloaded. Such job characteristics are related to the development of burnout syndrome (Maslach, Schaufeli, \& Leiter, 2001). Therefore, in the past 10 years, numerous studies and self-help books have been published about stress and burnout in helping professions. These recommend the personal resources and self-care activities that could be beneficial for these occupations (Norcross \& VandenBos, 2018).

\section{STRESS AND BURNOUT}

Burnout can be defined as a state of physical, emotional and mental exhaustion caused by long-term subsistence in extremely emotionally demanding work situations (Schaufeli \& Greenglass, 2001; Kristensen, Borritz, Villadsen, \& Christensen, 2005). Burnout syndrome has been described from the perspective of the tripartite component system which consists of emotional exhaustion, depersonalization and reduced personal accomplishment. It can be understood as a state with actual symptoms of physical and mental exhaustion or as a dynamic process (Maslach \& Goldberg, 1998; Schaufeli \& Buunk, 2003). In the procedural approach, burnout syndrome develops gradually in stages due to increasing stress and the inability of a person to cope with their excessive workload (Maslach et al., 2001; Schaufeli \& Buunk, 2003). The relationship between chronic stress and burnout is positive but not straightforward. In other words, stress alone does not cause burnout (Rothmann, Jackson, \& Kruger, 2003). The environmental and personal triggers as well as sup- pressors of burnout have been rigorously studied. The Job Demands-Resources model (Bakker \& Demerouti, 2007; Schaufeli, Bakker, \& Van Rhenen, 2009) and further Job Demands-Resources theory (Bakker \& Demerouti, 2014, 2017) assume that job demands may lead to energy depletion, exhaustion and other health related problems. Similarly, the Conservation of Resources theory (COR; Hobfoll, 1989; Hobfoll, Halbesleben, Neveu, \& Westman, 2018) suggests that the decrease of personal or job resources is connected to a steep increase of stress and could potentially lead to exhaustion. On the other hand, it has been found that satisfaction with personal or job resources might have a stress-reducing effect (Hobfoll et al., 2018).

\section{SELF-CARE}

Self-care is a complex of physical, psychological, mental and spiritual activities that are performed by an individual with the aim of maintaining or improving health (Carrol, Gilroy, \& Murra, 1999), physical and psychological well-being and personal growth (Godfrey et al., 2011; Lovaš, 2014). It is a selfregulated, deliberate and aim-oriented activity (Segall \& Goldstein, 1989; Lovaš, 2014). Self-care has been studied as a potential factor in preventing the development of negative outcomes in helping others such as burnout and compassion fatigue (Alkema, Linton, \& Davies, 2008; Carrol et al., 1999). It has also been said to promote positive outcomes such as compassion satisfaction or well-being (Alkema et al., 2008). Therefore, self-care represents a natural starting point for the prevention of burnout syndrome or other negative consequences of helping professions (Maslach \& Goldberg, 1998).

\section{THE PRESENT STUDY}

The aim of this study was to analyse and identify the possible mediators between stress and the three factors of burnout in a specific sample of helping professionals. Three models which examine the mediating role of self-care activities in the stress-burnout relationship were created.

\section{PARTICIPANTS AND PROCEDURE}

\section{PARTICIPANTS}

The research sample comprised 698 respondents from helping professions in the area of social and health services. Institutions which offer health support and social welfare services were randomly selected from a list on the Ministry of Labour, 
Social Affairs and Family's website. The selection was done using a random number generator. Fourteen institutions from all 8 districts in Slovakia were selected and recruited via mail and telephone communication. The contacted institutions that formally agreed to cooperate and were able to provide anonymity to the respondents were sent the test batteries. The response rate of the individuals from the institutions was $83.5 \%$. All subjects participated voluntarily. Following the ethical rules, the research was conducted as part of a large national study. From the original sample $(N=709)$, 15 outliers were identified by the Mahalanobis distances method and excluded from further analysis. The final sample $(N=698)$ consisted of 618 women (88.5\%), 80 men (10.6\%) and 6 without reported gender. The sample comprised social workers $(n=188)$; residential care providers $(n=191)$; ergotherapists $(n=97)$; providers of physical and psychological care (nurses, physiotherapists, psychologist and psychotherapists; $n=222$ ). The sample consisted of 252 professionals, who have a university education; other respondents have completed secondary education level. The average age of the participants is 43.9 years (20-65 years), $S D=10.40$. The average length of practice was 13.12 years (min 0 , max 44 years), $S D=10.47 .31 .3 \%$ of respondents worked directly with clients for more than 36 hours per week; $26.6 \%$ worked 28 hours per week and $17.5 \%$ of professionals worked up to 10 hours a week.

\section{MEASURES}

Perceived Stress Scale (PSS; Cohen, Kamarck, \& Mermelstein, 1983). A Slovak translation (Ráczová, Hricová, \& Lovašova, 2018) of this 10-item measure was used to assess the level of perceived stress among helping professionals. Respondents are asked to indicate the frequency of their feelings and thoughts during the last month on a 5-point scale from 1 (never) to 5 (very often); e.g. "In the last month, how often have you felt nervous and stressed?". A higher score indicates a higher level of perceived stress. In the current study, the reliability (McDonald's $\omega$ ) of the perceived stress scale was .79.

Maslach Burnout Inventory - Human Services Survey (MBI-HSS; Maslach, Jackson, \& Leiter, 1996). The inventory was translated in line with the purchased translation agreement (TA-673). The instrument consists of 22 items which measure three aspects of burnout syndrome, i.e. the level of emotional exhaustion (e.g. "I feel emotionally drained from my work"), depersonalization (e.g. "I don't really care what happens to some recipients") and reduced personal accomplishment (reverse coded, e.g. "I feel I'm positively influencing other people's lives through my work"). Respondents indicate the frequency of experiencing work-related feelings using a 7-point scale from 0 (never) to 6 (every day). McDonald's $\omega$ reliability estimates were .89 for emotional exhaustion, .72 for depersonalization and .78 for personal accomplishment. The omega reliability has been preferred over alpha reliability indicator by several authors (Cho \& Kim, 2015).

The Performed Self-Care Activities questionnaire (VSS; Lichner, 2017; Lichner, Halachová, \& Lovaš, 2018) is a 31-item questionnaire which measures performed activities in the sphere of self-care among helping professionals. Respondents are asked to answer how often they perform activities on a 5-point scale from 1 (never) to 5 (always). The questionnaire comprises four factors: psychological self-care (F1): maintaining good atmosphere and relationships at work, positive thinking, control of emotions (e.g. "I think positively"), professional self-care (F2): education, professional growth and self-development (e.g. "To cope with the workload I use professional growth"), health self-care (F3 - e.g. "In the case of health problems, I visit a doctor"), physical self-care (F4 - e.g. "I play sports"). In this study, McDonald's $\omega$ reliability estimate for psychological self-care was .87; .75 for professional self-care; .77 for health self-care and .76 for physical self-care.

\section{ANALYTIC PROCEDURE}

Three multiple mediation models using ordinary least squares path analysis were computed to analyse the data. The models were tested in Process Macro 3.1 in SPSS (Preacher \& Hayes, 2004). The assumptions were tested in view of a $95 \%$ bias-corrected confidence interval based on 10,000 bootstrap samples. The omega coefficients were computed in Jamovi 0.9.2.8.

\section{RESULTS}

The mean scores on the tested variables are presented in Table 1. As can be seen in Table 1, helping professionals perceived a higher level of stress $(M=3.99, S D=0.55)$. In self-care they preferred psychological $(M=4.22, S D=0.62)$ and health self-care $(M=3.92, S D=0.64)$. They perceived a low level of burnout depersonalisation $M=0.88(S D=0.99)$. On the other hand, their personal accomplishment was high $(M=4.66, S D=0.85)$.

From the correlation matrix (Table 2) it can be seen that all factors of self-care could mediate the relationship between stress and burnout. All forms of self-care are related to perceived stress in helping professions. All factors of self-care are in a significant negative relationship with the burnout factors of emotional exhaustion and depersonalization. In
Role of self-care in stress-burnout relationship 
Table 1

Means scores on tested variables

\begin{tabular}{lcccccccc}
\hline & \multirow{2}{*}{ PSS } & \multicolumn{4}{c}{ Self-care } & \multicolumn{3}{c}{ MBI } \\
\cline { 3 - 9 } & & VSS F1 & VSS F2 & VSS F3 & VSS F4 & MBI-E & MBI-D & MBI-PA \\
\hline Mean & 3.99 & 4.22 & 3.46 & 3.92 & 3.11 & 2.08 & 0.88 & 4.65 \\
Median & 3.80 & 4.28 & 3.50 & 4.00 & 3.00 & 1.88 & 0.67 & 4.50 \\
SD & 0.58 & 0.62 & 0.75 & 0.64 & 0.87 & 1.22 & 0.99 & 0.85 \\
\hline
\end{tabular}

Note. PSS - perceived stress, VSS F1 - psychological self-care, VSS F2 - professional self-care, VSS F3 - health self-care, VSS F4 physical self-care, MBI-E - burnout as emotional exhaustion, MBI-D - depersonalization, MBI-PA - personal accomplishment.

Table 2

Two-tailed Pearson correlation between used variables

\begin{tabular}{|c|c|c|c|c|c|c|c|c|}
\hline & \multirow[t]{2}{*}{ PSS } & \multicolumn{4}{|c|}{ Self-care } & \multicolumn{3}{|c|}{$\mathrm{MBI}$} \\
\hline & & 1 & 2 & 3 & 4 & 5 & 6 & 7 \\
\hline PSS & - & $-.32^{* *}$ & $-.27^{* *}$ & $-.21^{* *}$ & $-.17^{* *}$ & $.50^{* *}$ & $.32^{* *}$ & $-.36^{* *}$ \\
\hline 1 VSS F1 & $-.32^{* *}$ & - & $.51^{* *}$ & $.49^{* *}$ & $.26^{* *}$ & $-.19^{* *}$ & $-.24^{* *}$ & $.41^{* *}$ \\
\hline 2 VSS F2 & $-.27^{* *}$ & $.51^{* *}$ & - & $.34^{* *}$ & $.33^{* *}$ & $-.19^{* *}$ & $-.10^{*}$ & $.39^{* *}$ \\
\hline 3 VSS F3 & $-.21^{* *}$ & $.49^{* *}$ & $.34^{* *}$ & - & $.26^{* *}$ & $-.20^{* *}$ & $-.11^{* *}$ & $.19^{* *}$ \\
\hline 4 VSS F4 & $-.17^{* *}$ & $.26^{* *}$ & $.33^{* *}$ & $.26^{* *}$ & - & $-.13^{*}$ & $-.43^{* *}$ & $.14^{*}$ \\
\hline \multicolumn{9}{|l|}{$\mathrm{MBI}$} \\
\hline $5 \mathrm{MBI}-\mathrm{E}$ & $.50^{* *}$ & $-.19^{* *}$ & $-.19^{* *}$ & $-.20^{* *}$ & $-.13^{* *}$ & - & $.37^{* *}$ & $-.23^{* *}$ \\
\hline $6 \mathrm{MBI}-\mathrm{D}$ & $.32^{* *}$ & $-.24^{* *}$ & $-.10^{*}$ & $-.11^{*}$ & $-.43^{* *}$ & $.37^{* *}$ & - & $-.23^{* *}$ \\
\hline 7 MBI-PA & $-.36^{* *}$ & $.41^{* *}$ & $.39^{* *}$ & $.19^{* *}$ & $.14^{*}$ & $-.23^{* *}$ & $-.23^{* *}$ & - \\
\hline
\end{tabular}

Note. PSS - perceived stress, VSS F1 - psychological self-care, VSS F2 - professional self-care, VSS F3 - health self-care, VSS F4 physical self-care, MBI-E - burnout as emotional exhaustion, MBI-D - depersonalization, MBI-PA - personal accomplishment, ${ }^{*} p<.05,{ }^{*} p<.001$.

terms of the burnout factor of personal accomplishment, the situation is different. All factors of selfcare are in a positive significant relationship with the burnout factor personal accomplishment (Table 1).

Perceived stress predicted $26 \%$ of the variability of MBI - emotional exhaustion (Figure 1, Table 3). The total effect of the parallel multiple mediation analysis indicates that the model was significant, $R^{2}=.26, F(1,722)=316.18, p<.001(B=1.13$, $S E=.06, t=17.78, p<.001, \mathrm{CI}$ from 1.00 to 1.26$)$. The direct effect of stress on emotional exhaustion was significant $(B=1.09, S E=.07, t=15.10, p<.001, \mathrm{CI}$ from 0.95 to 1.23 ). The relationship between stress and emotional exhaustion was partially mediated through factor health self-care $(B=.04, S E=.02, \mathrm{CI}$ from .01 to .08). The other factors of self-care were not significant mediators. The assumptions were tested in view of a $95 \%$ bias-corrected confidence interval based on 10,000 bootstrap samples.

Perceived stress predicts a $10 \%$ variability in MBI - depersonalisation (Table 4, Figure 2). The overall effect of partial mediation was significant, $R^{2}=.10$, $F(1,722)=83.85, p<.001(B=.28, S E=.03, t=9.14$, $p<.001$, CI from .22 to .35). A significant direct relationship between perceived stress and MBI depersonalisation was identified $(B=.25, S E=.03$, $t=7.45, p<.001$, CI from .18 to .32 ). The relationship between perceived stress and depersonalisation was partially mediated by psychological selfcare $(B=.06, S E=.02$, CI from .03 to .09). Other factors of self-care were not significant mediators (Figure 2, Table 4). This means that psychological self-care reduces the risk of burnout in the form of depersonalisation, but it decreases in the event of a rise in stress.

The results from the model indicate that stress predicts $14 \%$ of variability in MBI - personal accomplishment (Figure 3, Table 5). The total effect of the parallel multiple mediation analysis was significant, $R^{2}=.14, F(1,722)=96.44, p<.001(B=-.58, S E=.06$, $t=-9.82, p<.001$, CI from -.69 to -.46$)$. The direct effect of stress on personal accomplishment was 


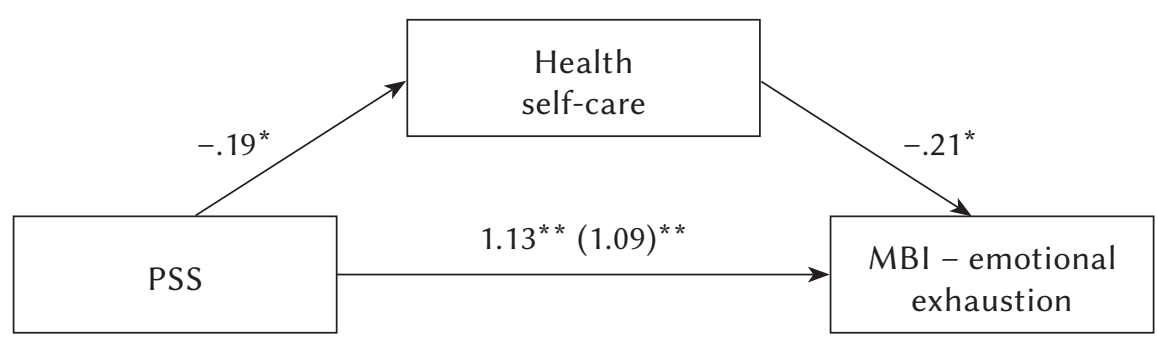

${ }^{*} p<.05,{ }^{* *} p<.001$

Figure 1. Multiple mediation model predicting MBI - emotional exhaustion. Only significant mediators are described.

Role of self-care in stress-burnout relationship
Table 3

Unstandardized direct and total effect and indirect effects in the model predicting $M B I-$ emotional exhaustion

\begin{tabular}{lcc}
\hline Mediator & $\begin{array}{c}\text { Bootstrap } \\
\text { estimate }(S E)\end{array}$ & $\begin{array}{c}95 \% \mathrm{Cl} \\
(\mathrm{LL}, \mathrm{UL})\end{array}$ \\
\hline
\end{tabular}

Direct effect

Stress $1.09(.07)$

$0.95,1.23$

Indirect effect

$\begin{array}{lrr}\text { VSS F1 } & -.02(.03) & -.09, .02 \\ \text { VSS F2 } & .02(.02) & -.02, .07 \\ \text { VSS F3 } & .04(.02) & .01, .08 \\ \text { VSS F4 } & .01(.01) & -.01, .04\end{array}$

Total effect

of the model

$1.13(.06) \quad 1.00,1.26$

Note. PSS - perceived stress, VSS F1 - psychological self-care, VSS F2 - professional self-care, VSS F3 - health self-care, VSS F4 - physical self-care; $95 \%$ confidence interval is significant when 0 is not included.
Table 4

Unstandardized direct and total effect and indirect effects in the model predicting $\mathrm{MBI}$ - depersonalization

\begin{tabular}{lcc}
\hline Mediator & $\begin{array}{c}\text { Bootstrap } \\
\text { estimate }(S E)\end{array}$ & $\begin{array}{c}95 \% \mathrm{Cl} \\
(\mathrm{LL}, \mathrm{UL})\end{array}$ \\
\hline $\begin{array}{c}\text { Direct effect } \\
\text { Stress }\end{array}$ & $.25(.03)$ & $.18, .32$ \\
$\begin{array}{c}\text { Indirect effect } \\
\text { VSS F1 }\end{array}$ & $.06(.02)$ & $.03, .09$ \\
VSS F2 & $-.01(.01)$ & $-.03, .01$ \\
VSS F3 & $-.01(.01)$ & $-.02, .01$ \\
$\quad$ VSS F4 & $-.01(.01)$ & $-.02, .01$ \\
$\begin{array}{l}\text { Total effect } \\
\text { of the model }\end{array}$ & $.28(.03)$ & $.22, .35$ \\
\hline
\end{tabular}

Note. PSS - perceived stress, VSS F1 - psychological self-care, VSS F2 - professional self-care, VSS F3 - health self-care, VSS F4 - physical self-care; $95 \%$ confidence interval is significant when 0 is not included.

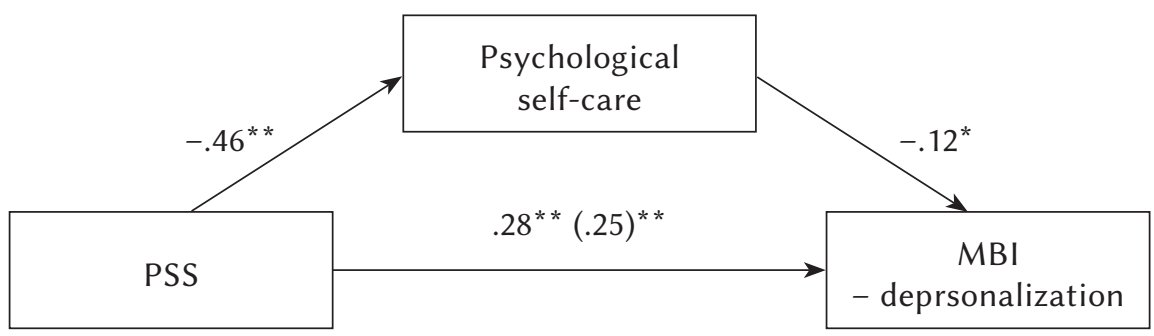

${ }^{*} p<.05,{ }^{* *} p<.001$

Figure 2. Multiple mediation model predicting MBI - depersonalization. Only significant mediators are described.

significant $(B=-.38, S E=.06, t=-6.19, p<.001, \mathrm{CI}$ from -.50 to -.26$)$. The relationship between stress and MBI - personal accomplishment was partially mediated through the factors of psychological selfcare $(B=-.12, S E=.03$, CI from -.18 to -.07$)$ and professional self-care $(B=-.10, S E=.02$, CI from -.15 to -.06) (Table 5, Figure 3). The other factors of self-care were not significant mediators in view of a 95\% bias-corrected confidence interval based on 10,000 bootstrap samples. 


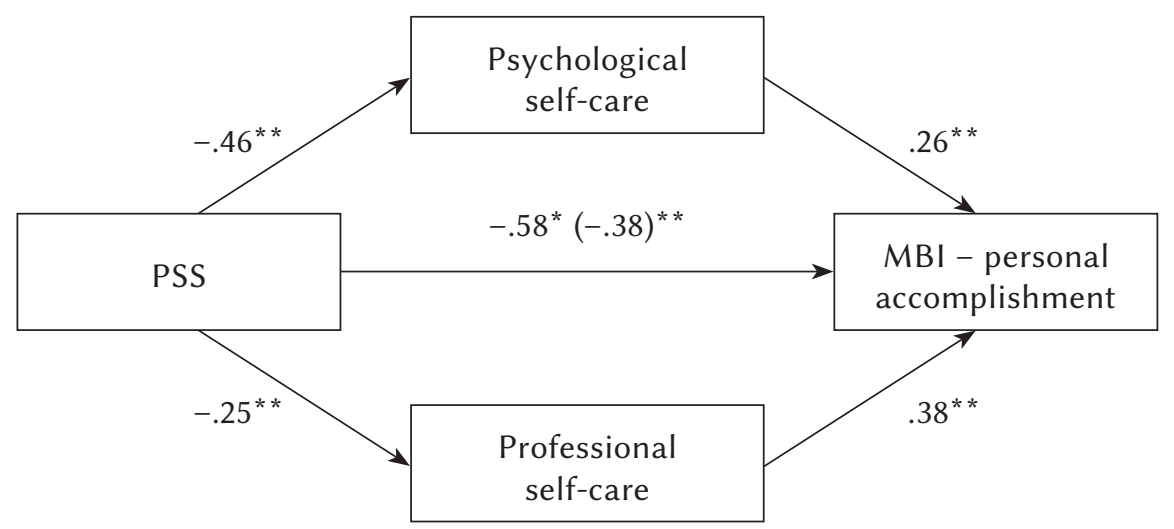

${ }^{*} p<.05,{ }^{* *} p<.001$

Figure 3. Multiple mediation model predicting MBI - personal accomplishment. Only significant mediators are described.

Table 5

Unstandardized direct and total effect and indirect effects in the model predicting MBI - personal accomplishment

\begin{tabular}{ccc}
\hline Mediator & $\begin{array}{c}\text { Bootstrap } \\
\text { estimate }(S E)\end{array}$ & $\begin{array}{c}95 \% \mathrm{Cl} \\
(\mathrm{LL}, \mathrm{UL})\end{array}$ \\
\hline $\begin{array}{c}\text { Direct effect } \\
\text { Stress }\end{array}$ & $-.38(.06)$ & $-.50,-.26$ \\
Indirect effect & & \\
VSS F1 & $-.12(.03)$ & $-.18,-.07$ \\
VSS F2 & $-.10(.02)$ & $-.15,-.06$ \\
VSS F3 & $.01(.01)$ & $-.01, .03$ \\
VSS F4 & $.01(.01)$ & $-.01, .03$ \\
$\begin{array}{l}\text { Total effect } \\
\text { of the model }\end{array}$ & $-.58(.06)$ & $-.69,-.46$ \\
\hline
\end{tabular}

Note. PSS - perceived stress, VSS F1 - psychological self-care, VSS F2 - professional self-care, VSS F3 - health self-care, VSS F4 - physical self-care; $95 \%$ confidence interval is significant when 0 is not included.

\section{DISCUSSION}

Helping professionals are exposed to multiple negative consequences as the result of helping others. Demerouti, Bakker, and Leiter (2014) have pointed out that it is important to pay attention to these phenomena, as they can affect both work performance and health. Our previous findings have shown that the most common source of stress in this population is the nature of the work itself, as it requires direct contact with people, dealing with their dissatisfaction, unclear client demands or aggressive behaviour. Cherniss (1999) has clarified that the long-term effects of stress and the inability to cope with an ex- cessive workload can lead to a change in the mental state of the individual. Long-term stress causes delayed activation of defence mechanisms and strategies for managing stressful situations, which is the reason for the gradual onset of signs of burnout (Maslach et al., 2001).

Self-care can act as a factor which eliminates the negative impact of the consequences of the helping professions. In connection with the negative consequences of helping, Figley (2002) has noted that helping professionals tend to overlook their own needs as they focus on the needs of clients. Self-care is an important factor which supports the ability of helping professionals to effectively assist others and can improve the quality of their work and personal lives (Mesárošová et al., 2017).

In this study, there were four areas of self-care which were monitored as mediators in the stressburnout relationship: psychological, professional, health and physical (active physical exercise). The relationship between stress and emotional exhaustion was mediated by health self-care. In times of increased stress, helping professionals could reduce the risk of burnout by engaging in health self-care activities (planning work activities, taking breaks at work, sleeping or seeing a doctor if health problems arise). Shapiro, Brown, and Biegel (2007) as well as Moore, Bledsoe, Perry, and Robinson (2011) have confirmed that the time devoted to oneself is positively reflected in more effective management of stress and improvement in occupational skills. In comparison, the relationship between stress and depersonalisation was mediated by psychological self-care. In times of increased stress, helping professionals could reduce the risk of depersonalisation by engaging in psychological self-care activities (creating positive social relationships and atmosphere in the home and work environments, striving to think positively). Our previous findings (Hricová, 2017) have shown that $27 \%$ of observed helping pro- 
fessionals had symptoms of emotional exhaustion while signs of depersonalisation were recorded in only $8 \%$ of helping professionals. This was predominantly found in residential childcare workers and social workers. In this regard, Maslach et al. (2001) have highlighted the burnout process where the intensity of burnout increases from the lowest to the highest level. Emotional exhaustion manifests itself in the initial stages of the process, followed by signs of depersonalisation (Kebza \& Šolcová, 2008). Health and psychological self-care were the most preferred self-care activities in our sample. Bloomquist, Wood, Friedmeyer-Trainor, and Kim (2015) noted that more frequent engagement in the field of psychological self-care was associated with lower levels of burnout and secondary traumatic stress.

The relationship between stress and personal accomplishment is mediated by both psychological and professional self-care (work preparation, supervision, education, rotation of work activities) that help increase personal accomplishment in times of stress. Since 2008, continuing professional development, continuing education and regular supervisions have been mandatory in Slovakia for all specialists in the helping professions. However, if professional development and supervision are mandatory, the role of personal engagement and self-regulation of the individual is lost. Self-care is defined as an individual's knowingly regulated, deliberate and self-initiated behaviour, where activities are performed on the basis of self-regulation (Lovaš, 2014; Godfrey et al., 2011). Therefore, if education and supervision are to fill a preventive and supportive role, they should be initiated by the individual. In addition, not all social service employers in practice offer the same quality, opportunities and safe environment for education and supervision. On the other hand, Slovak helpers perceive a high level of personal accomplishment at work (Hricová, 2017). Personal accomplishment is the counterpart to burnout (Maslach et al., 2001) and therefore it can be understood as one of the protective factors against the negative impacts in the helping professions. One of the limitations of this study may be the relatively simplified view of burnout that is predicted by stress and mediated by only a few self-care activities. This mechanism is likely to be much more complicated and not as direct and unidirectional as assumed. Moreover, it is known from the two-factor theory of stress that not all stress contributes to negative results. Stress can also lead to personal growth and improved performance (Podsakoff, LePine, \& LePine, 2007). The survey selection was not homogeneous as it included employees with different levels of education and different work focuses although working in the helping professions was a common factor. The survey was also limited by unequal age and gender representation although this corresponds to the proportionality of workers in this field, who are predominantly women over the age of 40 .

In conclusion, the results suggest that performing self-care activities can help reduce stress and can be understood as a preventive factor against burnout. In times of increased stress, helping professionals could reduce the risk of emotional exhaustion by engaging in health self-care activities. When helping professionals have initial symptoms of burnout in the form of emotional exhaustion, concentrating on health self-care activities could be helpful. In times of increased stress, helping professionals could reduce the risk of depersonalisation by engaging in psychological self-care activities. Psychological and professional self-care help to increase personal accomplishment in times of stress. This study agrees with Maslach et al. (2001) in that personal accomplishment is the counterpart to burnout and one other protective factor against the negative impacts in the helping professions. Employees should respect the specific needs of professional helpers, the variability of their personal resources or family situations in order not to further increase their current levels of perceived stress. Various educational events and self-development benefits should be offered.

\section{References}

Alkema, K., Linton, J. M., \& Davies, R. (2008). A study of the relationship between self-care, compassion satisfaction, compassion fatigue, and burnout among hospice professionals. Journal of Social Work in End-of-Life \& Palliative Care, 4, 101-119. https://doi.org/10.1080/15524250802353934

Bakker, A. B., \& Demerouti, E. (2007). The Job Demands-Resources model: State of the art. Journal of Managerial Psychology, 22, 309-328. https://doi. org/10.1108/02683940710733115

Bakker, A. B., \& Demerouti, E. (2014). Job demandsresources theory. In P. Y. Chen \& C. L. Cooper (Eds.), Wellbeing: A complete reference guide. Work and wellbeing (pp. 37-64). Chichester, UK: WileyBlackwell.

Bakker, A. B., \& Demerouti, E. (2017). Job demandsresources theory: Taking stock and looking forward. Journal of Occupational Health Psychology, 22, 273-285. https://doi.org/10.1037/ocp0000056

Barnett, J. E., \& Cooper, N. (2009). Creating a culture of self-care. Clinical Psychology: Science and Practice, 16, 16-20. https://doi.org/10.1111/j.14682850.2009.01138.x

Bloomquist, K. R., Wood, L., Friedmeyer-Trainor, K., \& Kim, H. W. (2015). Self-care and professional quality of life: Predictive factors among MSW Practitioners. Advances in Social Work, 16, 292-311. https://doi.org/10.18060/18760
Role of self-care in stress-burnout relationship 
Carrol, L., Gilroy, P. J., \& Murra, J. (1999). The moral imperative: Self-care for women psychotherapists. Women \& Therapy, 22, 133-143. https://doi. org/10.1300/J015v22n02_10

Cherniss, C. (1999). The business case for emotional intelligence. Retrieved from www.eiconsortium.org/ pdf/business_case_for_ei.pdf

Cho, E., \& Kim, S. (2015) Cronbach's coefficient alpha: Well known but poorly understood. Organizational Research Methods, 18, 207-230. https:// doi.org/10.1177/1094428114555994

Monika Hricová

Cohen, S., Kamarck, T., \& Mermelstein, R. (1983). A global measure of perceived stress. Journal of Health and Social Behavior, 24, 385-396. https:// doi.org/10.2307/2136404

Demerouti, E., Bakker, A. B., \& Leiter, M. (2014). Burnout and job performance: The moderating role of selection, optimization, and compensation strategies. Journal of Occupational Health Psychology, 19, 96-107. https://doi.org/10.1037/a0035062

Figley, C. R. (2002). Treating compassion fatigue. New York: Routledge.

Godfrey, C. M., Harrison, M. B., Lysaght, R., Lamb, M., Graham, I. D., \& Oakley, P. (2011). Care of self - care by other - care of other: the meaning of self-care from research, practice, policy, and industry perspective. International Journal of Evidence-Based Healthcare, 9, 3-24. https://doi. org/10.1111/j.1744-1609.2010.00196.x

Havrdová, Z., \& Šolcová, I. (2012). The relationship between workplace civility level and the experience of burnout syndrome among helping professionals. In V. Olisah (Ed.), Essential notes in psychiatry (pp. 13-36). Rijeka: InTechOpen.

Hobfoll, S. E. (1989). Conservation of resources: A new attempt at conceptualizing stress. American Psychologist, 44, 513-524. https://doi.org/10.1037//0003066x.44.3.513

Hobfoll, S. E., Halbesleben, J., Neveu, J. P., \& Westman, M. (2018). Conservation of resources in the organizational context: The reality of resources and their consequences. Annual Review of Organizational Psychology and Organizational Behavior, 5, 103-128. https://doi.org/10.1146/annurev-orgpsych-032117-104640

Hricová, M. (2017). Sebaregulácia pri dosahovaní cielov $v$ oblasit zdravia [Self-regulation in achieving health related goals]. Košice: Pavol Jozef Šafárik University in Košice.

Kebza, V., \& Šolcová, I. (2008). Syndrom vyhoření rekapitulace současného stavu poznání a perspektivy do budoucna [Burnout syndrome - review of contemporary state of knowledge and perspectives for the future]. Československá Psychologie, 52, 351-365.

Kristensen, T. S., Borritz, M., Villadsen, E., \& Christensen, K. B. (2005). The Copenhagen Burnout Inventory: A new tool for the assessment of burnout. Work \& Stress, 19, 192-207. https://doi. org/10.1080/02678370500297720

Lichner, V. (2017). Performed self-care in the context of resisting negative workplace consequences among Slovak social professionals. Canadian International Journal of Social Science and Education, 13, 312-320.

Lichner, V., Halachová, M., \& Lovaš, L. (2018). The concept of self-care, work engagement, and burnout syndrome among Slovak social worker. Czech and Slovak Social Work, 4, 62-75.

Lloyd, C., King, R., \& Chenoweth, L. (2002). Social work, stress and burnout: A review. Journal of Mental Health, 11, 255-265. https://doi.org/10. 1080/09638230020023642

Lovaš, L. (2014). Starostlivost̉ o seba a jej psychologické kontexty [Self-care and psychological contexts]. In L. Lovaš (Ed.), Psychologické kontexty starostlivosti o seba [Psychological contexts of self-care] (pp. 9-26). Košice: Pavol Jozef Šafárik University in Košice.

Mahoney, M. J. (1997). Psychotherapists' personal problems and self-care patterns. Professional Psychology: Research and Practice, 28, 14-16. https:// doi.org/10.1037/0735-7028.28.1.14

Maslach, C., \& Goldberg, J. (1998). Prevention of burnout: New perspectives. Applied and Preventive Psychology, 7, 63-74. https://doi.org/10.1016/ S0962-1849(98)80022-X

Maslach, C., Jackson, S. E., \& Leiter, M. P. (1996). Maslach Burnout Inventory (3rd ed.). Palo Alto, CA: Consulting Psychologists Press.

Maslach, C., Schaufeli, W. B., \& Leiter, M. P. (2001). Job burnout. Annual Review of Psychology, 52, 397-422. https://doi.org/10.1146/annurev.psych.52.1.397

Mesárošová, M., Köverová, M., Ráczová, B., Nezkusilová, J., Lichner, V., Lovaš, L., Lovašová, S., \& Hricová, M. (2017). Starostlivost' o seba a dôsledky vykonávania pomáhajúcich profesií [Self-care and the consequences of performing helping professions]. Košice: Pavol Jozef Šafárik University in Košice.

Moore, S. E., Bledsoe, L. K., Perry, A. R., \& Robinson, M. A. (2011). Social work students and selfcare. A model assignment for teaching. Journal of Social Work Education, 47, 545-553. https://doi. org/10.5175/JSWE.2011.201000004

Norcross, J. C., \& VandenBos, G. R. (2018). Leaving it at the office: A guide to psychotherapist self-care. New York: Guilford Press.

Podsakoff, N. P., LePine, J. A., \& LePine, M. A. (2007). Differential challenge stressor-hindrance stressor relationships with job attitudes, turnover intentions, turnover, and withdrawal behavior: A metaanalysis. Journal of Applied Psychology, 92, 438454. https://doi.org/10.1037/0021-9010.92.2.438

Preacher, K. J., \& Hayes, A. F. (2004). SPSS and SAS procedures for estimating indirect effects in simple mediation models. Behavior Research Methods, 
Instruments, \& Computers, 36, 717-731. https:// doi.org/10.3758/BF03206553

Ráczová, B., Hricová, M., \& Lovašová, S. (2018). Overenie psychometrických vlastností slovenskej verzie dotazníka PSS-10 (Perceived Stress Scale) na súbore pomáhajúcich profesionálov [Verification of psychometric properties of the Slovak version of the PSS-10 questionnaire (Perceived Stress Scale) on the sample of helping professionals]. Československá Psychologie, 62, 552-564.

Rothmann, S., Jackson, L. T. B., \& Kruger, M. M. (2003). Burnout and job stress in a local government: The moderating effect of sense of coherence. SA Journal of Industrial Psychology, 29, 52-60. https://doi. org/10.4102/sajip.v29i4.122

Schaufeli, W. B., Bakker, A. B., \& Van Rhenen, W. (2009). How changes in job demands and resources predict burnout, work engagement, and sickness absenteeism. Journal of Organizational Behavior, 30, 893-917. https://doi.org/10.1002/job.595

Schaufeli, W. B., \& Buunk, A. B. (2003). Burnout: An overview of 25 years of research and theorizing. In M. J. Schabracq, J. A. M. Winnubst, \& C. L. Cooper (Eds.), The handbook of work and health psychology (pp. 383-425). Hoboken, NJ: Wiley.

Schaufeli, W. B., \& Greenglass, E. R. (2001). Introduction to special issue on burnout and health. Psychology \& Health, 16, 501-510. https://doi. org/10.1080/08870440108405523

Segall, A., \& Goldstein, J. (1989). Exploring the correlates of self-provided health care behaviour. Social Science \& Medicine, 29, 153-161. https://doi. org/10.1016/0277-9536(89)90163-9

Shapiro, S. L., Brown, K. W., \& Biegel, G. M. (2007). Teaching self-care to caregivers: Effects of mindfulness-based stress reduction on the mental health of therapists in training. Training and Education in Professional Psychology, 1, 105-115. https://doi. org/10.1037/1931-3918.1.2.105

Whitaker, T., Weismiller, T., Clark, E., \& Wilson, M. (2006). Assuring the sufficiency of a frontline workforce: A national study of licensed social workers. Special report: Social work services in health care settings. Washington, DC: National Association of Social Workers. 